\title{
CHOLESTEROL TUMOUR (GRANIOPHARYNGIOMA) OF THE PITUITARY BODY
}

\author{
By \\ F. PARKES WEBER, C. WORSTER-DROUGHT, and \\ W. E. CARNEGIE DICKSON, LoNdon \\ GLINIGAL CASE
}

THE patient, when 47 years of age, was shown by one of us (F. P. W.), in May, 1927, at the Clinical Section of the Royal Society of Medicine with the diagnosis 'Pituitary (cystic ?) Tumour.' 1 He had then a pale, cachectic appearance, with somewhat wizened, shrivelled face; moderate anæmia ; more or less chronic headache, especially in the upper occipital region; bilateral temporal hemianopia and, on radiographic examination, considerable anteroposterior enlargement of the pituitary fossa. A negative Wassermann reaction was obtained in both blood serum and cerebrospinal fluid, and the latter was normal in all other respects. There was no polyuria. Bloodsugar (May 17, 1927) was 0.082 per cent. The blood-sugar curve was not abnormal. The blood pressure was $126 \mathrm{~mm}$. $\mathrm{Hg}$. systolic; $88 \mathrm{~mm}$. $\mathrm{Hg}$. diastolic. The patient had no axillary hair and only scanty hair on pubes, eyebrows and face, and he stated that he never had had any more than this. The testicles were rather small. He had four children, all living and healthy, but had been sexually impotent for the past year.

He dated his symptoms from an attack of influenza about February, 1925, and in the summer and autumn of that year had been found already to have anæmia, headache, bilateral temporal hemianopia and enlargement of the pituitary fossa. Later, in February, 1926, there had been some improvement. Afterwards he progressed fairly well and was able to continue his work as dock clerk until his fatal illness of September, 1933.

A radiogram of the sella turcica region taken in September, 1933, showed the dorsum sellæ indistinct and the pituitary fossa enlarged, apparently measuring $12 \mathrm{~mm}$. in length and $11 \mathrm{~mm}$. in depth.

He died from an acute diarrhœal febrile disease. Morgan's bacillus was cultivated from the fæces and his blood-serum gave a positive agglutination reaction for the dysentery bacillus of Sonne, but this latter reaction may have been due to a past dysenteric infection.

\section{PATHOLOGICAL EXAMINATION}

At autopsy (September 30, 1933), a globular tumour was seen projecting from the position of the pituitary fossa (fig. 1, a). Its appearance suggested that of a small round chestnut with a comparatively smooth 
external surface, brownish in general colour, but with mottled darker brown patches of old hæmorrhage just beneath the surface; and a thin elastic crackly parchment- or shell-like capsule, fibrous and with some slight calcification. The compressed optic nerves passed obliquely forwards from beneath each side of the tumour, while further back the middle cerebral artery was seen passing forwards, outwards and upwards. The measurements of the mass were : anteroposterior diameter, $30 \mathrm{~mm}$. ; transverse, $28 \mathrm{~mm}$. ; vertical, $30 \mathrm{~mm}$.- -i.e. it was almost an exact sphere. The anteroposterior measurement of the shallow pituitary fossa was $23 \mathrm{~mm}$. from the situation of the slight

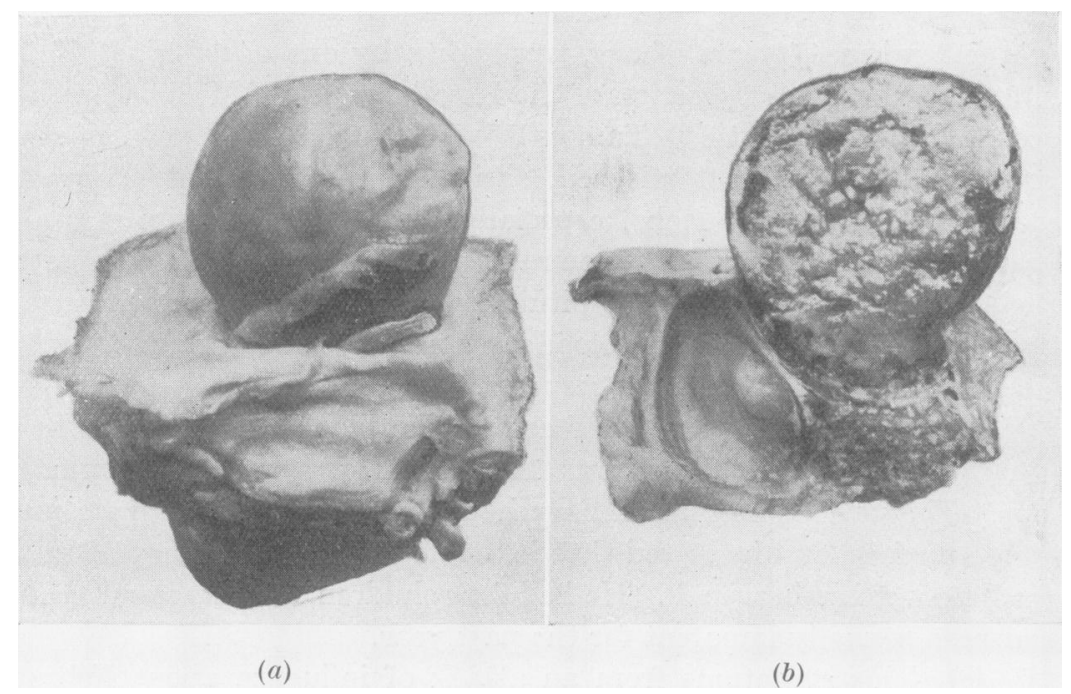

Fig. 1.-Naked-eye photographs of tumour after removal. (a) Right lateral aspect (illustration $2 \mathrm{~mm}$. smaller than actual size) shows the general appearance of the tumour projecting upwards from the sella. The right optic nerve and middle cerebral artery are seen passing obliquely forwards and upwards. (b) Mesial sagittal section (actual size) shows the crumbling cholesteatomatous contents of the cyst and the subcapsular hæmorrhages, the shallow eroded sella with the compressed remains of the pituitary body on its floor and the sphenoidal sinus in the body of the bone.

prominences representing the flattened-out remains of the almost completely destroyed clinoid processes.

On median vertical section, the mass was found to consist of crumbling, loose, semi-necrotic rather dry-looking granular to slightly soapy débris, mixed with innumerable fine cholesterol crystals glistening like frost (fig. 1, $b$ ). Here and there towards the periphery there was a small amount of firmer pearly-white fibrous tissue shading off into the softer and more central material, evidently largely amorphous or necrotic. There were several red to brownish subcapsular hæmorrhages of varying ages to which the mottled appearance of the outside of the tumour was due. The sella was enlarged, eroded and shallow, its saucer-like concavity being occupied by a thin layer of more or 
less degenerated or necrotic-looking tissue, rapidly shading off above into the general contents of the cyst; the whole section was rather reminiscent of the shape of a 'button mushroom' with a wide stalk attached below to the shallow floor of the sella and with its interior undergoing decay.

\section{MICROSCOPICAL EXAMINATION}

Fresh wet films of the contents of the cyst showed a mixture of granular débris with numerous typical crystalline plates of cholesterol, together with

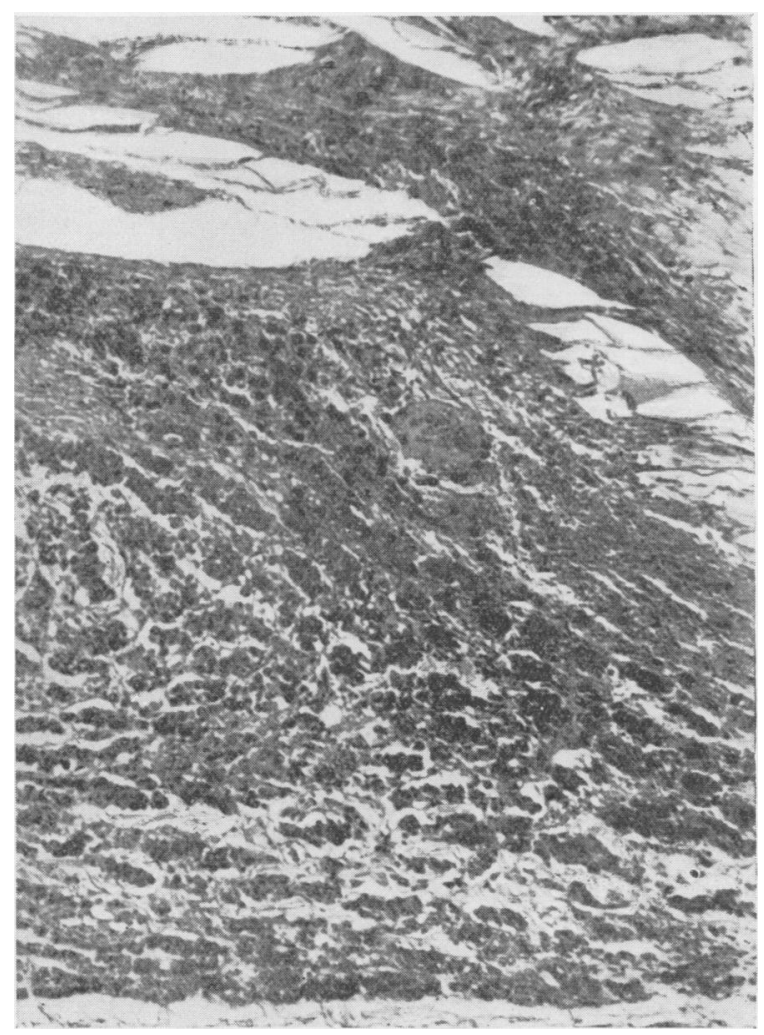

FIG. 2.-A low-power photograph of the compressed pituitary glandular tissue, stripped from the floor of the sella, the whole thickness of which is included in a single low-power field. The glandular acini are compressed and atrophied, with an increase of connective tissue between them. Some of the cholesterol. clefts are shown at the upper part of the photograph, and it will be noted that there is no irritative cellular reaction around them, unless there is some other cause of this, such as hæmorrhage or inflammation. No squamous epithelial cells have survived in this area. Hæmatoxylin and cosin. $\times 200$ diam.

the disintegrating remains of a few cells, the nature of which in these preparations was now unrecognisable, and red blood corpuscles both hæmolysed and fresh. 
Sections in continuity were somewhat difficult to obtain, owing to the crumbling nature of the specimen. In the intrasellar or basal portion, there was, at the margin, a thin compressed layer of much degenerated pituitary glandular tissue, the surviving cells being chiefly eosinophil with only an occasional basophil cell (see figs. 2 and 3) mixed with proliferated connective tissue of varying density. Internal to (i.e. above) this were the contents of the cyst, which were composed of much granular and amorphous débris

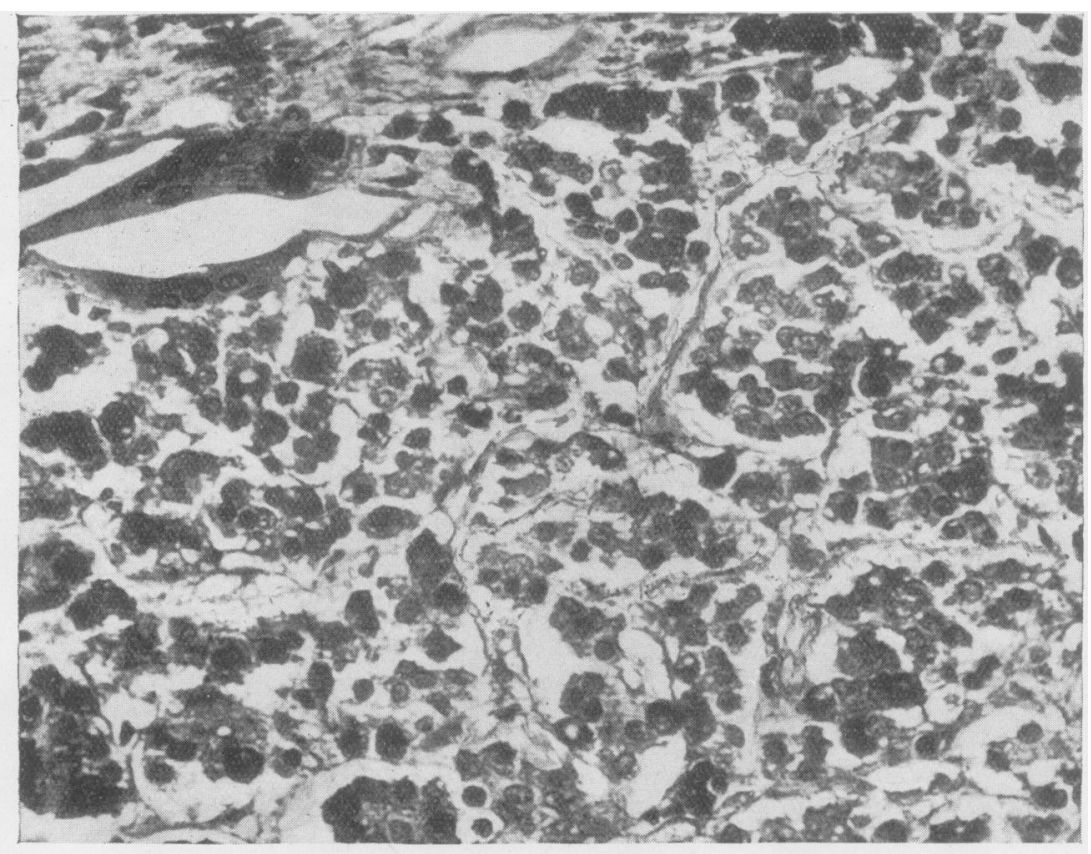

FIG. 3.-High-power photograph of an area of surviving pituitary glandular cells from the floor of the sella. Some cholesterol-clefts are seen at the upper left corner, with some degenerated remnants of squamous epithelium around them (compare with next figure), this part of the section corresponding with the capsule covering the upper surface of the gland. The surviving cells in the plane of this mesial section are predominantly eosinophil. There is rather less fibrosis in this particular area than in some other parts. Hæmatoxylin and eosin. $\times 400$ diam.

together with old degenerated and hyaline connective-tissue trabeculæ (the latter most continuous and distinct towards the periphery), between and amongst which were very numerous cholesterol-clefts of varying size lying at all angles to one another (fig. 4). Around most of these clefts there was no irritative cellular reaction, their immediate surroundings being either dense, almost non-cellular fibrous tissue, or non-cellular amorphous and structureless degenerative material. Here and there, but practically only towards the periphery, in or just under the connective-tissue capsule, the faint outlines of degenerated cells could be made out; there were also numerous hæmor- 
rhages, both recent and old. It was only in, or in the immediate neighbourhood of, these hæmorrhagic areas that such cells were found. The latter were mostly 'foam-cells' as well as other varieties of phagocytic tissue- and wandering cell, but with only an occasional polymorph (i.e. there was no suppurative reaction), together with some scanty collections of small round and plasma-cells, and also some young connective-tissue cells-again mostly in areas where there was a considerable amount of blood-pigment ; probably these represented a chronic irritative phenomenon accompanying and following upon the hæmorrhage. No squamous epithelium or any adamantinoma-

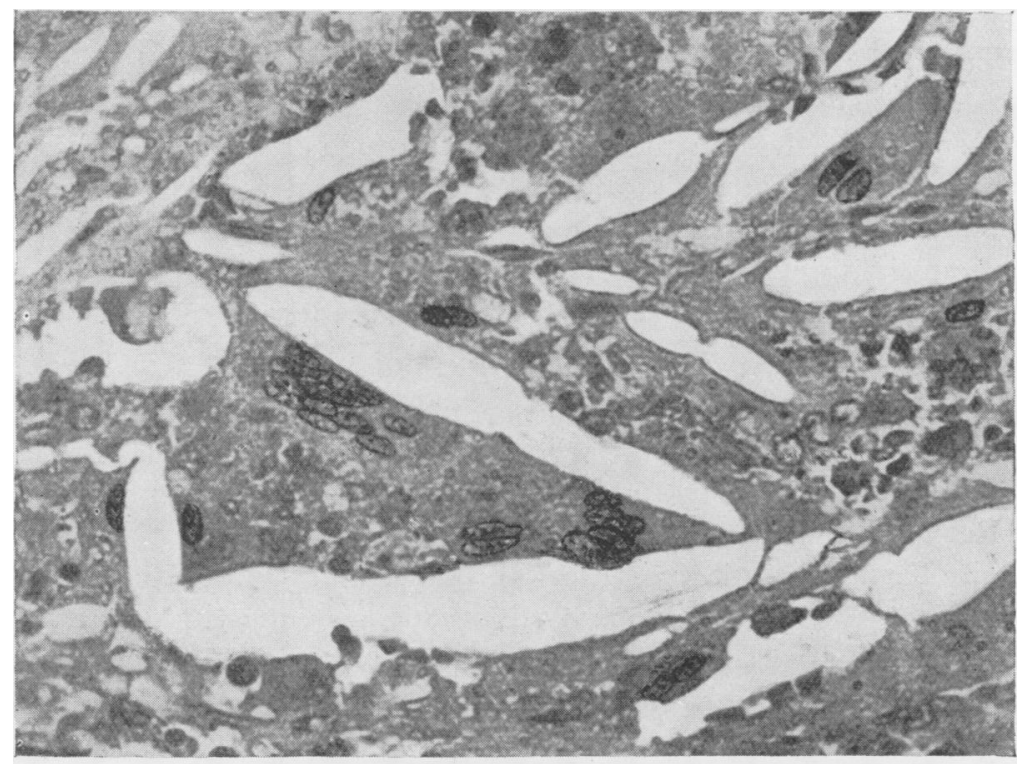

Fig. 4.-High-power photograph of some of the cholesterol-clefts just beneath the fibrous capsule. Round some of these are seen the last surviving squamous epithelial cells from which the tumour originated. These cells tend to become plasmodial and multinucleated as they degenerate. All stages of this process can often be traced in similar cases, but in the present instance only these extremely scanty and much degenerated cells were found in many sections examined. Van Gieson and hæmatoxylin. $\times 500$ diam.

tous tissue could be detected throughout the main mass of the tumour, but very occasionally, around some of the cholesterol-clefts towards the periphery, there were a few irregular and degenerated large plasmodial cells (fig. 4) which appeared to be the last remaining survivors of the squamous epithelium from which this cystic tumour had evidently originated, i.e. the tumour was a squamous-celled suprapituitary craniopharyngioma or hypophyseal-duct tumour. It had arisen from squamous remnants of the duct, which had persisted in one of the common sites for such remnants, viz. in the capsule covering the upper surface of the pituitary gland. Another common site is the anterior surface of the infundibulum. 
The domed 'roof' or capsule of the tumour consisted of dense, rather hyaline fibrous tissue, mostly comparatively non-cellular except in and around the hæmorrhagic areas, and, as already noted, with only the minimal remains of any squamous epithelium here and there in the deeper part of the capsule. In the superficial layer of the latter were abundant patches of finely granular dark golden-brown blood-pigment, which gave the typical Prussian blue reaction of hæmosiderin-mostly free in the tissue spaces, but, near the more recent hæmorrhages, still contained within mononuclear phagocytes.

\section{SUMMARY}

The tumour is, therefore, a very old-standing (congenital) squamouscelled craniopharyngiomatous or hypophyseal-duct cyst which has become cholesteatomatous with almost complete disappearance, by a process of ' natural cure,' of the squamous cells from which it originated. In other words, it is not a Rathke's pouch or intraglandular-cleft tumour. The pituitary gland itself has undergone very extensive pressure atrophy, the thin layer of surviving glandular cells-at all events in the mesial plane represented in the sections examined-being predominantly eosinophil.

\section{COMMENTARY}

The group of craniopharyngiomas comprises all the squamous epithelial intracranial growths of the pituitary region, both cysts and solid formations. Thus the lesions variously termed hypophyseal-duct tumours, suprasellar cysts, Rathke's pouch tumours, ameloblastomas and adamantinomas are all included. Their origin is congenital and, although symptoms may develop at any age from the first to the seventh decade, they most frequently appear in childhood and adolescence. The modified cubical-celled epithelium, which at first lines the hypophyseal duct, normally disappears, but from its remnants may develop squamous epithelial tumours. These develop from the anterior surface of the infundibulum (suprasellar or supradiaphragmatic craniopharyngioma) or, as in the present case, from beneath the capsule covering the anterior pituitary lobe (intrasellar or subdiaphragmatic craniopharyngioma). In the latter form, the pituitary body is compressed; its remains are usually found in flattened crescentic form in some part of the floor of the sella. It is frequent to find these remains only on microscopical examination.

Among 80 cases of craniopharyngioma analysed by Cushing, ${ }^{2}$ in only seven did the first symptoms appear in the fifth decade. The age-distribution in the series was as follows :-

\begin{tabular}{|c|c|c|c|c|c|}
\hline 1st & cade & & & 15 & ises \\
\hline 2nd & , , & • & & 27 & , \\
\hline 3rd & , & - & - & 15 & , \\
\hline 4th & , & . & . & 10 & , \\
\hline 5 th & , & - & • & 7 & ", \\
\hline 6th & , , & • & • & 4 & , \\
\hline 7th & ,, & . & . & 2 & , \\
\hline
\end{tabular}


In the younger cases interference with the normal secretory activity of the anterior pituitary lobe is from the outset usually manifest by retarded growth and imperfect genital development. Obesity is also frequent. When symptomatic evidence of the lesion is postponed until the fourth decade or later, growth and development may have been normal; the initial symptom is then usually some visual disturbance, e.g. hemianopia or papillœdema. As in the case we record, it is not infrequent at this age for the patient to present a pale and cachectic appearance with wrinkled skin and reduced bodily hair. Impotence is the rule, and polyuria is very frequent; this latter symptom was not present in our patient. The blood-pressure is often very low, even in adults. Cushing records a systolic pressure of $60 \mathrm{~mm}$. (diastolic $50 \mathrm{~mm}$.) in a patient aged 23 , and $80-90 \mathrm{~mm}$. systolic is not infrequent.

\section{REFERENGES}

1 Weber, F. Parkes, Proc. Roy. Soc. Med., 1927, 20, 1336.

2 Cushing, H., Pituitary Body and Hypothalamus, 1932, 51. 